\title{
Association of a DNA Virus with Grapevines Affected by Red Blotch Disease in California
}

\author{
Maher Al Rwahnih, Ashita Dave, Michael M. Anderson, Adib Rowhani, Jerry K. Uyemoto, and Mysore R. Sudarshana
}

First, second, and fourth authors: Department of Plant Pathology, third author: Department of Viticulture and Enology, and fifth and sixth authors: United States Department of Agriculture, University of California, One Shields Av., Davis 95616. Accepted for publication 15 April 2013.

\begin{abstract}
Al Rwahnih, M., Dave, A., Anderson, M. M., Rowhani, A., Uyemoto, J. K., and Sudarshana, M. R. 2013. Association of a DNA virus with grapevines affected by red blotch disease in California. Phytopathology 103:1069-1076.

In the Napa Valley of California, vineyards of 'Cabernet Franc' (CF) clone 214, 'Cabernet Sauvignon' clone 337, and 'Zinfandel' clone 1A (Z1A) with grapevines exhibiting foliar symptoms of red blotches, marginal reddening, and red veins that were accompanied by reduced sugar accumulation in fruit at harvest were initially suspected to be infected with leafroll-associated viruses. However, reverse-transcription polymerase chain reaction (PCR) tests were negative for all known leafroll-associated viruses, with the exception of Grapevine leafrollassociated virus 2 in Z1A. Metagenomic analysis of cDNA libraries obtained from double-stranded RNA enriched nucleic acid (NA) preparations from bark scrapings of dormant canes on an Illumina platform
\end{abstract}

ABSTRACT

Grape (Vitis vinifera L, family Vitaceae) production is a major enterprise in the state of California, where vineyards account for $90 \%$ of the bottled wines in the United States (http://www. wineinstitute.org), and nearly all of the table grape berries and raisins produced in the country. The North Coast region of California is a major producer of premium quality wine grape berries. Currently, there are $\approx 45,000$ acres of wine grape planted in Napa County which command the highest price per ton in California.

Grape production can be impacted by several pests and diseases. Among grapevine diseases caused by viruses and viruslike agents, leafroll diseases significantly impact vineyard health $(13,29)$. Currently, there are 11 leafroll-associated viruses that have been recognized as members of the family Closteroviridae (28). Recently, Martelli et al. (28) proposed to regroup these viruses into five species: Grapevine leafroll-associated virus 1 (GLRaV-1), GLRaV-3, and GLRaV-4, under the genus Ampelovirus; GLRaV-2, in the genus Closterovirus; and GLRaV-7 under the new genus Velarivirus. Of these, GLRaV-1 and GLRaV-3 are major concerns due, in part, to their wider distribution and being vectored by several species of mealy bugs and scales $(10,16$, $26,37)$. The lone leafroll-associated virus belonging to the genus Closterovirus, GLRaV-2, despite its adverse effect on grapevine health and wine quality, is not considered epidemiologically significant because it is not known to be vectored $(7,18)$.

Corresponding author: M. R. Sudarshana; E-mail address:

mysore.sudarshana@ars.usda.gov

http://dx.doi.org/10.1094/PHYTO-10-12-0253-R

This article is in the public domain and not copyrightable. It may be freely reprinted with customary crediting of the source. The American Phytopathological Society, 2013 revealed sequences having a distant relationship with members of the family Geminiviridae. Sequencing of products obtained by PCR assays using overlapping primers and rolling circle amplification (RCA) confirmed the presence of a single circular genome of 3,206 nucleotides which was nearly identical to the genome of a recently reported Grapevine cabernet franc-associated virus found in declining grapevines in New York. We propose to call this virus "Grapevine red blotch-associated virus" (GRBaV) to describe its association with grapevine red blotch disease. Primers specific to GRBaV amplified a product of expected size (557 bp) from NA preparations obtained from petioles of several diseased source vines. Chip bud inoculations successfully transmitted GRBaV to test plants of CF, as confirmed by PCR analysis. This is the first report of a DNA virus associated with red blotch disease of grapevines in California.

Additional keywords: geminivirus, next-generation sequencing.

In grapevines, leafroll disease is recognized by green secondary and tertiary veins and interveinal purple to red discoloration of leaf blades in red fruit varieties or pale green to yellow color in white fruit varieties (13). Diseased grapevines decline slowly and the clusters suffer from berries lacking full color, delayed maturity, and reduced sugar (16). Wines produced from grape affected by leafroll disease are inferior in quality $(21,25)$.

Some strains of leafroll-associated viruses, such as GLRaV-2 and GLRaV-7, can be asymptomatic in nature $(3,31,38)$. For example, GLRaV-2 strain RG is asymptomatic in 'Red globe' table grape and 'Cabernet Franc' clone 01, the indicator host of most leafroll-associated viruses, including the type strain of GLRaV-2 (38). In addition to leafroll, several red leaf diseases involving degenerative symptoms on woody cylinders of grapevine trunks have been recognized in grapevines in California $(2,4,38)$. In a few cases, the etiological agent remains unknown despite arduous investigations $(2,4)$. Even so, during the past decade, much attention has been given to the characterization and recognition of viruses of importance in the context of plant health and berry production. Concomitantly, several new grapevine viruses have been described in recent years in symptomatic and asymptomatic grapevines $(1,2,5,11,24,30,40)$. Application of metagenomic analysis aided by the next-generation sequencing technology has been pivotal in the discovery of some of the new viruses $(2,33)$.

Recently, vineyards in Napa County planted to red fruited varieties were observed to develop leafroll-like symptoms (8). However, symptoms consisted of red blotches on leaf blade and leaf margin with red secondary and tertiary veins. Fruit on affected grapevines measured $\approx 2.4^{\circ}$ Brix lower than fruit from grapevines with green canopies (8). Herein, we describe the association of a DNA virus, recently described as Grapevine 
cabernet franc-associated virus $(\mathrm{GCFaV})(23)$, in grapevines affected by red blotch disease.

\section{MATERIALS AND METHODS}

Vineyard visits and specimens. In fall 2009, three commercial vineyards planted to Cabernet Franc clone 214 (CF214) on rootstock 101-14 at Oakville, 'Cabernet Sauvignon' clone 337 (CS337) on roostock O39-16 at Rutherford, and 'Zinfandel' 1A (Z1A) on roostock AxR\#1 at Calistoga, and an experimental vineyard of the University of California (UC)-Davis planted to Cabernet Sauvignon 7 (CS-7) on rootstock 101-14 at Oakville, all located in Napa County, CA, containing several grapevines with leafroll-like symptoms were monitored. Several of the diseased grapevines had been marked by the vineyard managers and these grapevines had tested negative for leafroll viruses, with the exception of GLRaV-2 in Z1A (virus assays were performed by commercial virus testing service providers in California). At these sites, we categorized foliar symptoms, cane growth, and evidence of any trunk markings. Woody canes were harvested in November 2010 from single symptomatic grapevines of CF214, CS337, and $\mathrm{Z} 1 \mathrm{~A}$ and stored at $4^{\circ} \mathrm{C}$. A control sample of dormant canes was also collected from 'Pinot Noir' clone 91 (PN) grapevine in the UC-Davis vineyard maintained by the Foundation Plant Services.

Quantitative reverse-transcription polymerase chain reaction assays for grapevine viruses. Bark scrapings of dormant canes were obtained, ground using a coffee grinder (Mr.Coffee; Sunbeam Products Inc., Boca Raton, FL), and stored at $-80^{\circ} \mathrm{C}$ until processed. Total RNA was extracted from a subsample of ground bark scrapings of symptomatic CF214, CS337, and Z1A sources using the RNeasy plant mini kit (www.quiagen.com) and analyzed for grapevine viruses by quantitative reverse-transcription polymerase chain reaction (qRT-PCR) using TaqMan probes on the ABI 7900 HT Fast real-time PCR system (www.invitrogen. com), as described previously $(19,32)$. TaqMan probes used in the assays were targeted to leafroll-associated viruses and their strains, including GLRaV-1, GLRaV-2, GLRaV-2RG, GLRaV-3, GLRaV-4, GLRaV-7, and GLRaV-4 strains 9 and Car; maculavirus Grapevine fleck virus; nepoviruses Grapevine fanleaf virus, Tobacco ringspot virus, and Tomato ringspot virus; vitiviruses Grapevine virus A (GVA), GVB, and GVD; and foveavirus Grapevine rupestris stem-pitting associated virus (GRSPaV).

Double-stranded RNA extraction and deep sequencing of nucleic acid extracts from bark scrapings. Nucleic acid (NA) enriched for double-stranded (ds)RNA was extracted from $30 \mathrm{~g}$ of ground bark scrapings as per Routh et al. (34) but without the DNase and RNeasy treatment. Complementary (c)DNA libraries were prepared using the SuperScript II Reverse Transcriptase kit (www.invitrogen.com) primed with random hexamers $(300 \mathrm{ng} / \mathrm{\mu l}$, www.invitrogen.com) and amplified with GenomePlex complete whole genome amplification kit (www.sigmaaldrich.com) as per the manufacturer's instructions but without the fragmentation step. The amplified DNA preparation was cleaned using a PCR cleanup kit (www.sigmaaldrich.com) and the DNA quality was verified as described previously (2).

Sequence data was generated by Eureka Genomics Inc. (www. eurekagenomics.com) using an Illumina Genome Analyzer IIx (www.illumina.com). From each sample, an Illumina indexed library was prepared from $1 \mu \mathrm{g}$ of cDNA for single-end, multiplexed sequencing on Genome Analyzer IIx. Briefly, the cDNA was fragmented, end repaired, A-tagged, ligated to adaptors, size selected, and enriched with 18 cycles of PCR. Sample preparation was performed according to a proprietary method of Eureka Genomics Inc. and Illumina's Multiplexing Sample Preparation Guide. For each library, two lanes of single-end 36-cycle reads of sequence data were generated and the resulting sequence reads were filtered using the default parameters of the Illumina QC pipeline (CASAVA) and demultiplexed. Reads from each of the samples were used to generate de novo assembly using algorithm Velvet (39) and data analysis was done at the National Center for Biotechnology Information (NCBI) (http://www.ncbi.nlm.nih. gov/) using BLASTN for highly similar (megablast) and somewhat similar nucleotide sequences (blastn) and BLASTX (6). The contigs used for these analyses were at least 100 nucleotides (nt) in length.

Detection of a DNA virus in grapevines exhibiting red blotch symptoms by PCR. The sequences of contigs from CF214, CS337, and Z1A were subjected to multiple sequence alignment using CLUSTALW (http://www.genome.jp/tools/clustalw/) and two primers, GVGF1 (5'-CTCGTCGCATTTGTAAGA-3') and GVGR1 (5'-ACTGACAAGGCCTACTACG-3'), were designed based on the identical regions in the three contigs. Nucleic acid extracts were prepared from leaf petioles of grapevines with red blotch symptoms in Napa County using a MagMAX-96 Viral RNA Isolation Kit (www.invitrogen.com) as per the manufacturer's protocol. Amplification of the target was achieved by PCR using primers GVGF1 and GVGR1 and GoTaq (www. promega.com) on an Eppendorf EP Mastercyler $S$ (www. eppendorf.com). Thermocycling conditions included 1 cycle of $94^{\circ} \mathrm{C}$ for $2 \mathrm{~min} ; 35$ cycles of $94^{\circ} \mathrm{C}$ for $30 \mathrm{~s}, 60^{\circ} \mathrm{C}$ for $30 \mathrm{~s}$, and $72^{\circ} \mathrm{C}$ for $1 \mathrm{~min}$; and 1 cycle of $72^{\circ} \mathrm{C}$ for $5 \mathrm{~min}$. The amplified products were analyzed by agarose gel electrophoresis using Trisacetate-EDTA (TAE) buffer and sequenced using GVGF1 and GVGR1 primers by Sanger sequencing at the UC-Davis sequencing facility (http://dnaseq.ucdavis.edu).

Determination of the genome of the virus associated with grapevines affected by red blotch disease. Nucleic acid extract from three diseased source grapevines was subjected to isothermal rolling circle amplification (RCA) (17) using the Illustra TempliPhi 100 amplification kit (www.gelifesciences.com). A $2-\mu \mathrm{l}$ aliquot of the total NA extract was added to $5 \mu \mathrm{l}$ of sample buffer, denatured for $3 \mathrm{~min}$ at $95^{\circ} \mathrm{C}$, and cooled to room temperature. After adding $5 \mu \mathrm{l}$ of reaction buffer and $0.2 \mu \mathrm{l}$ of enzyme mix, the reaction mix was incubated overnight $(18$ to $20 \mathrm{~h})$ at $30^{\circ} \mathrm{C}$ and stopped by incubation at $65^{\circ} \mathrm{C}$ for $10 \mathrm{~min}$. Aliquots $(2 \mu \mathrm{l})$ of the RCA products in a $10-\mu \mathrm{l}$ volume were digested separately by restriction enzymes BamHI, EcoRI, and PstI (www. neb.com) for $2 \mathrm{~h}$ and the digested products were analyzed by electrophoresis on a $1 \%$ agarose gel in TAE buffer. Subsequently, the RCA products were cleaned using Zymoclean DNA cleaning kit (www.zymoresearch.com) and sequenced.

The full genome of the DNA virus was also amplified using a Phusion High-Fidelity DNA polymerase (www.neb.com) and two overlapping primers, GVGA-01 (5'-CATATCTGCAGGAATC GC-3') and GVGA-02 (5'-CAATCTGCAGTTCTAGTGAAAG$3^{\prime}$ ), on the ABI 9800 Fast Thermal Cycler. The thermocycling conditions used included 1 cycle of $98^{\circ} \mathrm{C}$ for $30 \mathrm{~s} ; 35$ cycles of $98^{\circ} \mathrm{C}$ for $10 \mathrm{~s}, 52^{\circ} \mathrm{C}$ for $30 \mathrm{~s}$, and $72^{\circ} \mathrm{C}$ for $90 \mathrm{~s}$; and 1 cycle of $72^{\circ} \mathrm{C}$ for $7 \mathrm{~min}$. The amplified product was purified using the Qiaquick PCR purification kit (www.qiagen.com) and the nucleotide sequence was determined by primer walking on both strands, starting with the primers GVGA-01 and GVGA-02.

Graft transmission assays. Shoots from source grapevines of CF214, CS337, and Z1A were obtained in September 2011 and, after confirmation by PCR, the bud chips were grafted onto test plants of CF01 maintained in a greenhouse. Nucleic acid preparations were obtained at 4 and 11 months postinoculation from leaf petioles distal to the bud grafts and at 11 months postinoculation from root tips, and PCR assays were conducted as described above.

\section{RESULTS}

Symptoms of grapevine red blotch. Three commercial vineyards located at Calistoga, Oakville, and Rutherford in Napa 
County CA, and the Oakville Experimental Vineyard of UCDavis were inspected during fall 2009-2011. Disease symptoms consisted of leaves with irregular red blotches, red veins, and occasional marginal reddening (Fig. 1). The basal leaves were more symptomatic than the middle leaves and the terminal leaves generally remained free from symptoms (Fig. 1D). The leaf margins looked normal, except in the case of Z1A, where some rolling down of leaf margin was evident. The affected vineyards included plantings of CF214 at Oakville, CS07 at Oakville Experimental vineyard of UC-Davis, CS337 at Rutherford, and Z1A at Calistoga.

qRT-PCR assay for known grapevine viruses. Total RNA preparations from sources of CF214 and CS337 were tested for grapevine viruses using qRT-PCR assays employing TaqMan probes for five leafroll-associated viruses, one maculavirus, three nepoviruses, and three vitiviruses. Both sources of disease samples tested positive for only GRSPaV. All positive controls and negative controls reacted in the expected manner.

Deep sequencing. Once the qRT-PCR assays using TaqMan probes failed to indicate the presence of any of the 15 known grapevine viruses, metagenomic analysis was attempted on the cDNA libraries prepared using dsRNA fractions from CF214, $\mathrm{CS} 337$, and Z1A not treated with nucleases. The Illumina sequence reads varied from 6.8 to 8.1 million among the cDNA libraries prepared from three diseased sources and healthy PN (Table 1). Of these, $\approx 30 \%$ were unique reads and the total sequence data generated from each library ranged from nearly 247 to $292 \mathrm{Mb}$.
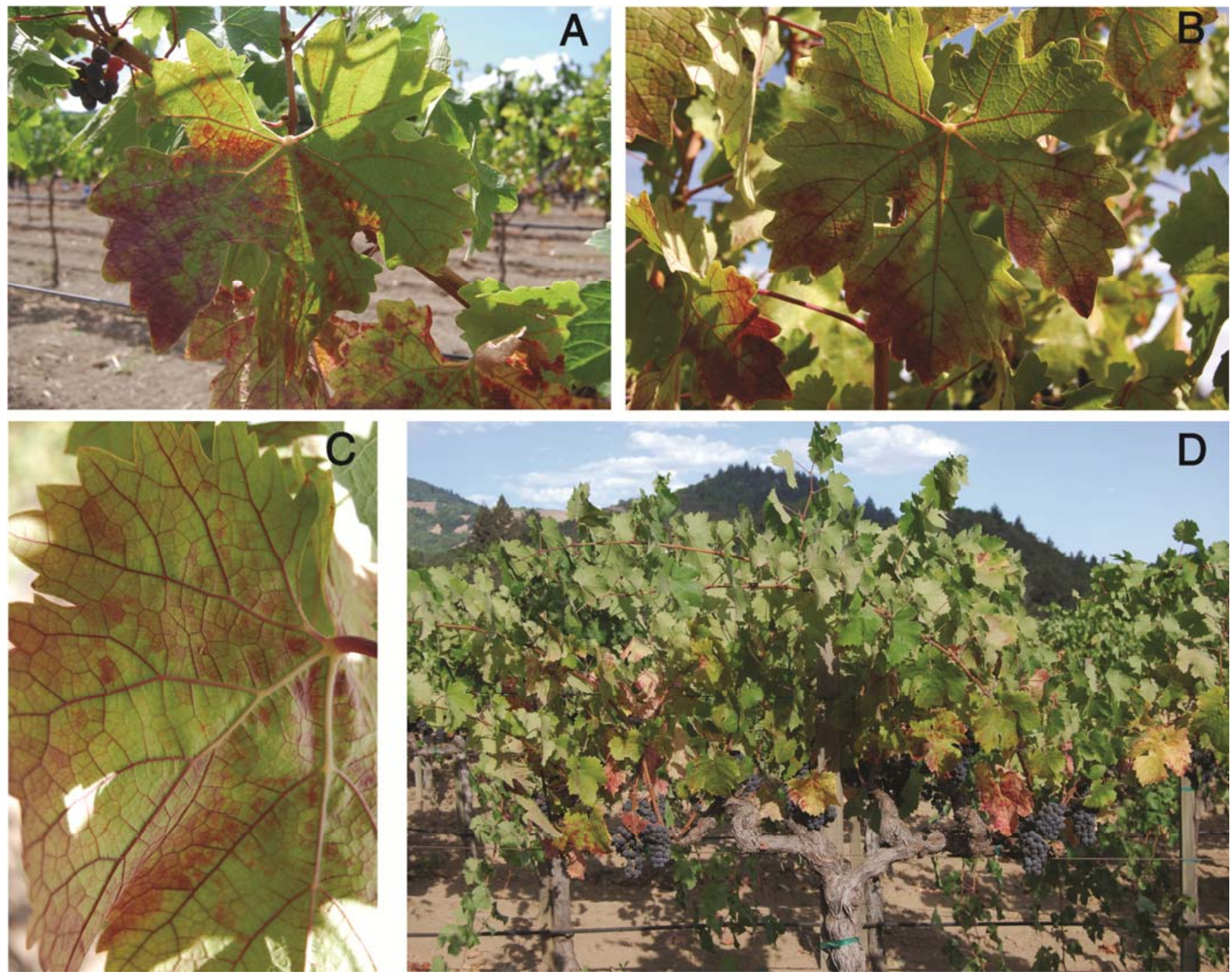

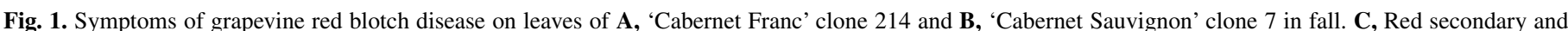

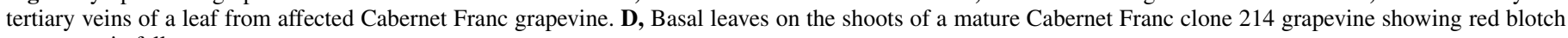
symptoms in fall.

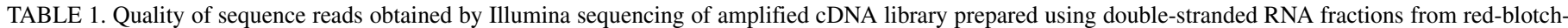
diseased grapevines

\begin{tabular}{|c|c|c|c|c|}
\hline Grapevine cultivar & Total number of reads & Number unique & Unique $(\%)$ & Sequence $(\mathrm{Mb})$ \\
\hline Cabernet Franc $214^{\mathrm{a}}$ & $8,131,042$ & $2,556,465$ & 31.4 & 292 \\
\hline Cabernet Sauvignon $337^{\mathrm{a}}$ & $6,877,920$ & $2,205,584$ & 32.0 & 247 \\
\hline Zinfandel $1 \mathrm{~A}^{\mathrm{a}}$ & $7,961,669$ & $2,518,810$ & 31.6 & 286 \\
\hline Pinot noir $91^{\mathrm{b}}$ & $7,008,854$ & $2,021,920$ & 28.8 & 252 \\
\hline
\end{tabular}

a Diseased source plants from commercial vineyards in Napa County.

${ }^{\mathrm{b}}$ Healthy control from a vineyard maintained by the Foundation Plant Services, University of California, Davis. 
The longest contig assembled comprised 16,430 nt from the cDNA library from source Z1A. Subsequent bioinformatics analysis indicated that this contig sequence was $99 \%$ identical to a GLRaV-2 sequence in the NCBI database (www.ncbi.nlm. nih.gov). The second-longest contig from Z1A was 3,242 bases long and had very limited homology with Chickpea chlorotic dwarf Syria virus (CCDSV) (36) in BLASTN analysis. A 3,224base-long contig from source CS337 also showed very limited homology with CCDSV. In contrast, a slightly shorter contig, 1,711 bases, from source CF214 showed a distant relationship with Mesta yellow vein mosaic virus but only in BLASTX analysis. The BLASTN analysis also revealed the presence of GRSPaV in libraries from the sources CF214 and CS337 but not from the sources Z1A and PN, consistent with the RT-PCR data. However,

A

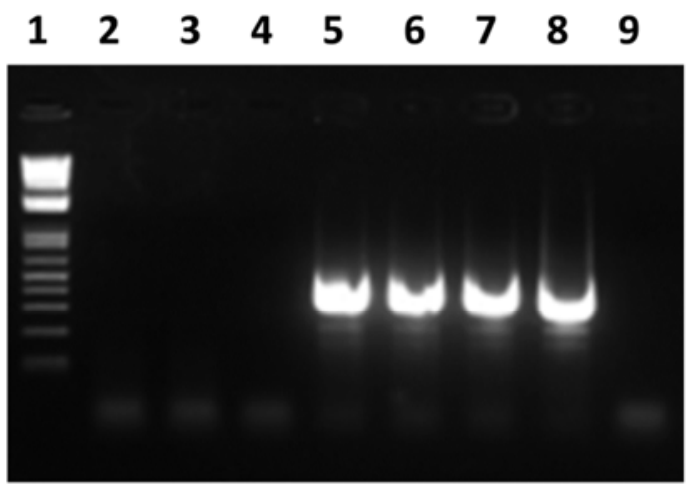

B
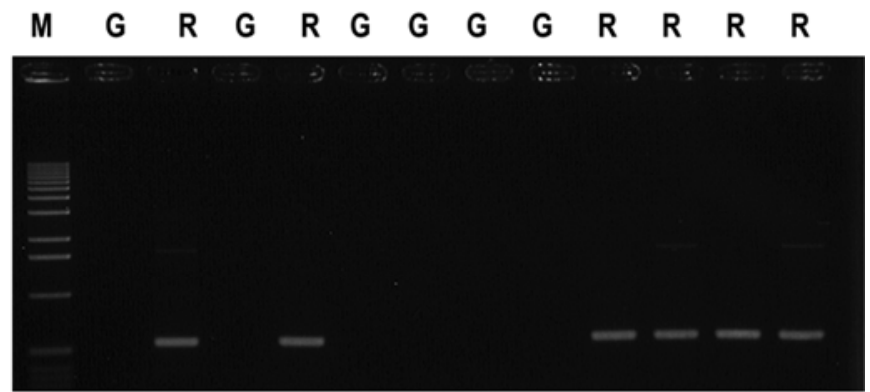

$\begin{array}{llllllllllll}\mathbf{R} & \mathbf{R} & \mathbf{R} & \mathbf{R} & \mathbf{R} & \mathbf{R} & \mathbf{R} & \mathbf{R} & + & - & \mathbf{W}\end{array}$

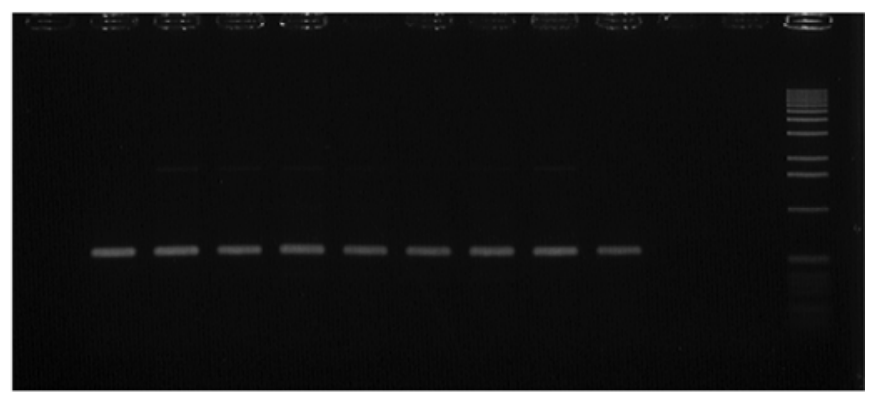

Fig. 2. Detection of Grapevine red blotch-associated virus (GRBaV) using primers GVGF1 and GVGR1 in grapevines. A, Detection of the virus in symptomatic source vines used for deep sequencing. Lane 1, 1-kb-plus ladder (Invitrogen Inc., Carlsbad, CA); lanes 2 to 4, healthy 'Cabernet Franc' plants from greenhouse; lanes 5 to 7, symptomatic source vines CF214, CS337, and Z1A; lane 8, DNA library used for deep sequencing; lane 9, water. B, Detection of GRBaV by polymerase chain reaction in a vineyard planted with 'Cabernet Sauvignon' clone 7 at the University of California-Davis Enology and Viticulture Station at Oakville in July 2012 before the onset of symptoms. Lane M, 1-kb DNA ladder (Invitrogen Inc.); lanes 1 to 20, nucleic acid extracts from 20 plants; lane G, grapevines with green canopy in 2011; lane R, grapevines with red blotch symptoms in 2011; lane + , positive control as above; lane -, healthy CF01; lane W, water control. these two assembled contigs, 4,304 and 5,638 nt, respectively, shared $\approx 79 \%$ identity between them, thus representing two genetically diverse strains of GRSPaV. Sequences of several mycoviruses, belonging to the families Chrysoviridae and Totiviridae, were also found, but not in the DNA libraries of all three source grapevines with red blotch symptoms. Mycovirus sequences were also found in PN, which did not show any red blotch symptoms.

Detection of a DNA virus in grapevines from red-blotchaffected vineyards. Nucleotide sequences of three contigs from CF214, CS337, and Z1A which showed limited relationship with geminiviruses were aligned using CLUSTALW, and two primers were designed to amplify a product of $557 \mathrm{bp}$. Initial PCR analysis amplified a product of expected size from NA preparations from diseased sources of CF214, CS337, and Z1A and also from cDNA libraries used for deep sequencing (Fig. 2A). Subsequent PCR assays conducted on NA preparations from three symptomatic CF214 plants in Oakville vineyard indicated the presence of the virus in diseased CF214 plants but not in healthy CF01 plants from UC-Davis vineyard (Fig. 2A). The nucleotide sequence of the amplified products matched the contig sequences generated by Illumina sequencing. Several symptomatic grapevines close to the source vines were also confirmed as infected by the virus in PCR analysis (data not shown).

In July 2012, in a limited survey in an experimental vineyard of Cabernet Sauvignon at the Enology and Viticulture Station of UC-Davis at Oakville, NA preparations of leaf petioles from 20 grapevines were assayed by PCR before the onset of symptoms. In all, 10 of these vines were from the end of a block, with disease incidence close to $100 \%$ in fall 2011 , and the other 10 were from the end, where the disease incidence was low. After the completion of PCR assay, the vineyard was visited in September 2012 and the disease status of tested vines was recorded. All vines that were positive for the virus in PCR (Fig. 2B) were symptomatic while those that were negative for the virus were symptomless. These results confirmed that a DNA virus was associated with grapevines showing red blotch symptoms and the virus was tentatively called "Grapevine red blotch-associated virus" (GRBaV).

The new DNA virus genome resembles a monopartite geminivirus. The full genome sequence of the GRBaV was determined from a 3.2-kbp PCR product amplified from NA from symptomatic CF214 grapevine using two overlapping primers, GVGA-01 and GVGA-02. The amplified product was initially sequenced using the primers used for amplification and subsequently by genome walking using several additional primers. The circular genome comprises 3,206 nt, with a nonanucleotide sequence typical of geminiviruses. The intergenic region (IR) contained the characteristic inverted repeat capable of forming a stem-loop structure. A highly conserved nonanucleotide sequence (TAATATTAC) was also present within the loop of the IR, similar to those found in the IR of three representative geminiviruses (Fig. 3A). Predictions using Simvector 4.6 (www.premierbiosoft. com) indicated six open reading frames (ORFs): V2 (292 to 807), V1 $(710$ to 1,384$)$, and V3 $(1,365$ to 1,736$)$ in sense orientation and C2 (1,898 to 2,332), C1 (2,250 to 3,044$)$, and C3 (2,408 to 2,890 ) in complimentary orientation (Fig. 3B). In BLASTP analysis, the predicted amino acid sequence of $\mathrm{V} 2$ had no relationship with virus-encoded proteins in the public domain database (www.ncbi.nlm.nih.gov) but the V1 gene was predicted to encode the capsid protein, which had $28 \%$ identity $(46 / 165)$ with Mesta yellow vein mosaic virus (GenBank JX242516). The $\mathrm{C} 1$ and C2 ORFs had the capacity to encode for the replicationassociated proteins sharing homology with C1 and C2 of Srilankan Cassava mosaic virus (GenBank CAI64619) and Miscanthus streak virus (GenBank BAA25579), respectively.

While these studies were in progress, BLAST searches showed that $\mathrm{GRBaV}$ found in grapevines with red blotch disease was nearly identical to GCFaV found in grapevines in New York State 
(GenBank JQ901105). Although the nucleotide sequences of the virus isolates $\mathrm{CF} 214-1$ and Z1A-1 were nearly identical to $\mathrm{GCFaV}$, the sequence of the virus isolate from CS337-1 (3,207 nt) shared $92.7 \%$ identity with GCFaV.

To determine whether the GRBaV genome is monopartite or bipartite, the circular NA genome was amplified using RCA. The amplified products, when digested by restriction enzymes BamHI,
EcoRI, and PstI and separated by agarose gel electrophoresis, revealed restriction patterns that could be expected from in silico analysis of the nucleotide sequence from full-length PCR product obtained using overlapping primers GVG01 and GVG02. The BamHI digest produced two fragments of $\approx 1.6 \mathrm{~kb}$ from RCA products of sources CF214 and Z1A but not of source CS337. The PstI digest produced a monomer of $3.2 \mathrm{~kb}$ from RCA products

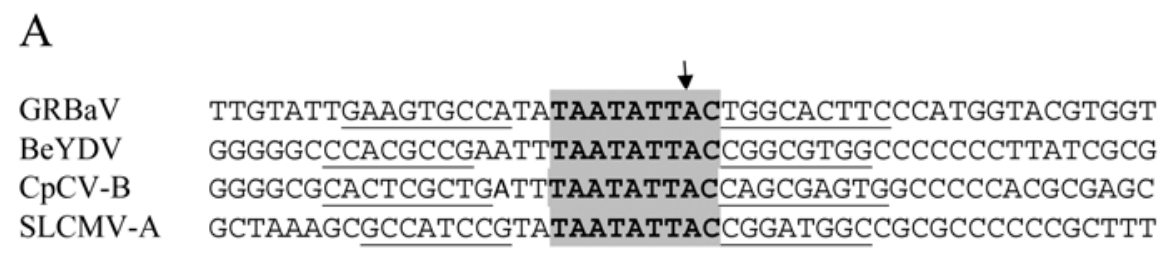

B

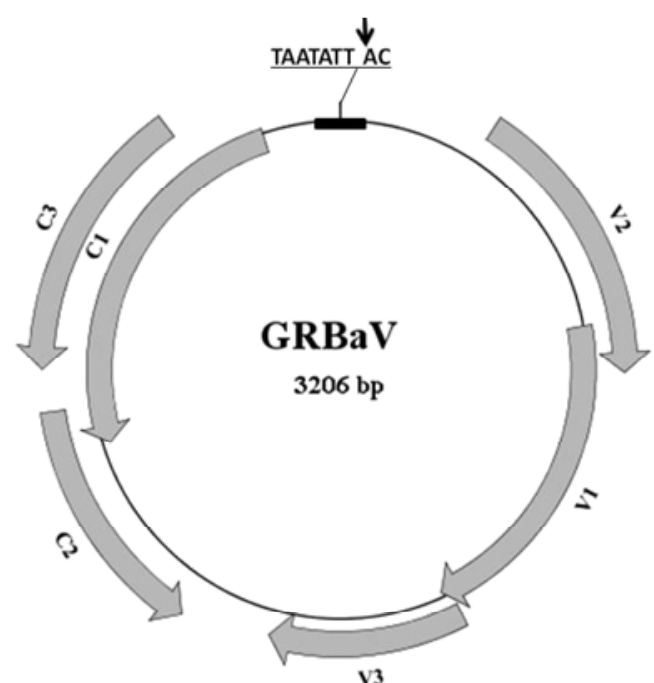

Fig. 3. A, Intergenic region (IR) showing nonanucleotide sequence of Grapevine red blotch-associated virus (GRBaV) aligned with three geminiviruses: Bean yellow dwarf virus (BeYDV; DQ458791.1), Chickpea chlorosis virus-B (CpCV-B;GU256531.1), and Sri Lankan cassava mosaic virus (SLCMV-A, AJ890228). B, Circular genome of GRBaV showing six open reading frames. The nonanucleotide sequence containing the origin of replication is in bold (A). The origin of replication is marked with a downward arrow. Underlined sequences are complimentary and form the stem.

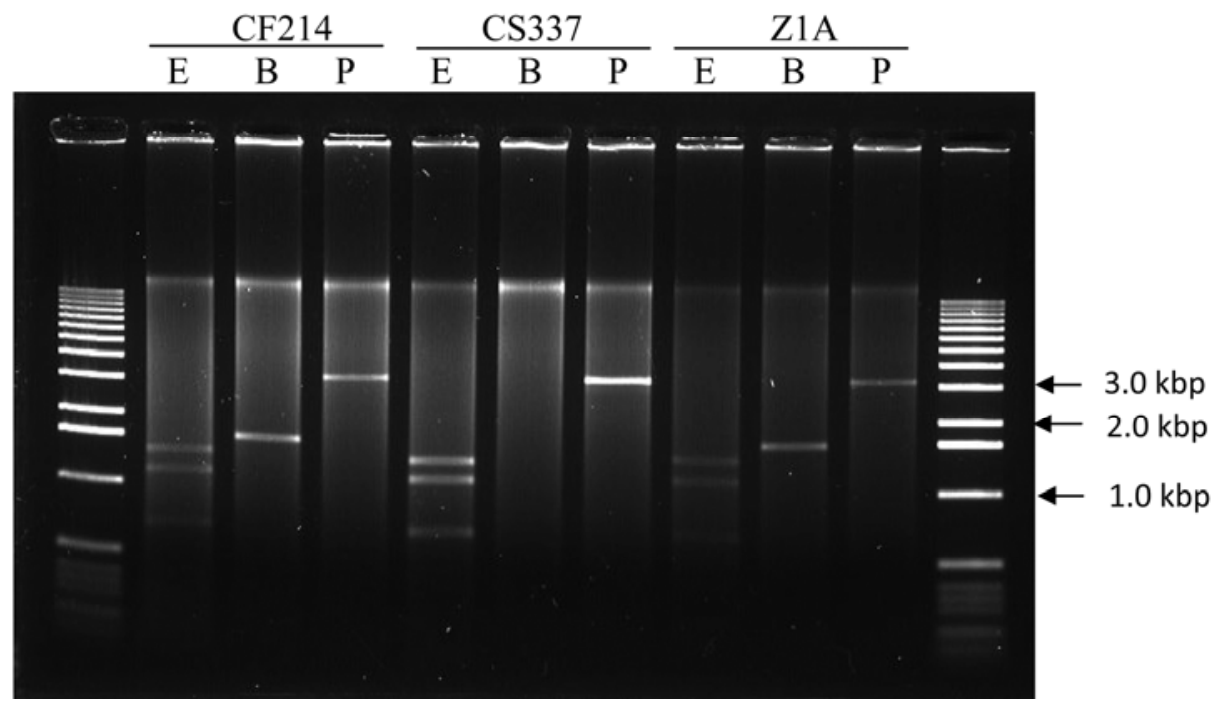

Fig. 4. Restriction analysis of the amplified products obtained from rolling circle amplification of nucleic acid extracts from red-blotch-diseased grapevines of 'Cabernet Franc' (CF214), 'Cabernet Sauvignon' (CS337), and 'Zinfandel' (Z1A). Lanes at both ends are 1-kb DNA ladder (Invitrogen Inc., Carlsbad, CA). B = BamHI, E = EcoRI, and $\mathrm{P}=$ Pst 
obtained from all three sources (Fig. 4). Apparently, two point mutations in the virus sequence from CS337 had eliminated the BamHI sites. Digestion by EcoRI produced three fragments and their migration pattern matched those of 680-, 1,140-, and 1,386 -bp fragments predicted by in silico analysis. Taken together, restriction fragment analysis using three restriction enzymes indicated that the virus genome is monopartite in nature. The complete sequences of CF214-1, derived from a full-length amplified product, and CS337-1 and Z1A-1, derived from sequences obtained by Illumina sequencing, are available as GenBank accessions KC896623, KC896624, and KC896625, respectively.

Graft-transmission assays. Graft transmissibility of the DNA virus was assessed by chip bud inoculations using bud chips from diseased sources of CF214, CS337, and Z1A onto five CF01 test plants per source. The grafted plants were examined by PCR analysis at 4 and 11 months postinoculation. At 4 months, the virus was not detected in NA extracts from petiole samples taken from the leaves distal to the grafted area. However, bark samples close to the graft site tested positive for the virus (data not shown). At 11 months postinoculation, petioles from some leaves distal to the graft sites of inocula sources of CF214 and CS337 tested positive in PCR assays (Table 2). Also, roots of most test plants grafted with all three inocula sources were positive. During the 1-year observation period, none of the infected test plants developed symptoms of red blotch disease.

\section{DISCUSSION}

Grapevine represents one of the most widely grown clonally propagated perennial crops in the world. In many parts of the world, vineyards are established on clonally propagated rootstocks. Before quarantine protocols were established, unregulated movement of propagation materials contributed to spread of several grapevine viruses. In some instances, the presence of a virus (latent in scion), when propagated on different rootstocks or grown in widely different climatic regions, served to induce graft incompatibility reactions $(14,15,38)$, resulting in red leaf symptoms and rapid decline and death of grapevines. Quite often, the red leaf symptoms are distinct from the leafroll symptoms caused by the members of the genera Ampelovirus and Closterovirus (family Closteroviridae) $(4,38)$.

In Napa Valley, a new red leaf disease was recognized and later named "grapevine red blotch disease" (8). Symptomatic grapevines showed leaves with red veins, often accompanied by red blotches (Fig. 1). Although symptoms such as red veins are occasionally seen in leaves suffering from physical damage or stress, red primary veins are not seen in grapevines showing leaf roll disease. Molecular assays for known grapevine viruses were largely negative and a few positives did not correlate with assays of multiple collections. Hence, we proceeded to make cDNA libraries using dsRNA-enriched NA fractions from diseased source vines of CF214, CS337, and Z1A planted in separate vineyards. During NA preparations, RNAse and DNAse treatments were deliberately avoided to include viruses with DNA genomes, such as Grapevine vein clearing virus (40).

In metagenomic analysis, among the contigs generated from Illumina reads, a fairly long sequence of GLRaV-2 was found in the library from source Z1A. Contigs of two genetically different GRSPaVs, one each from sources CF214 and CS337, were also revealed. These sequences shared $80 \%$ identity over 4,300-nt length. Contigs of several mycoviruses were also encountered but these were not seen in all three libraries from diseased sources. Detailed bioinformatics analysis of three contigs, one each of sources CF214, CS337, and Z1A, indicated a weak relationship at the amino acid level with proteins encoded by geminiviruses. However, the relationship with the four recognized genera (Mastrevirus, Curtovirus, Begomovirus, and Topocuvirus) of the family Geminiviridae was very poor. These results established that the DNA virus present in diseased grapevines was the putative agent of red blotch disease and, hence, we proposed to call this virus GRBaV. While this manuscript was in preparation, $\mathrm{GCFaV}$, tentatively grouped under the family Geminiviridae, was reported from grapevines in New York State (23). Bioinformatics analysis revealed that $\mathrm{GRBaV}$ was closely related to $\mathrm{GCFaV}$, and GRBaV isolates CF214-1 and Z1A-1 were nearly identical to GCFaV. However, GRBaV isolate CS337-1 was only 93\% identical to $\mathrm{GCFaV}$ and, thus, represents a genetically different strain. Incidentally, the New York isolate was obtained from declining grapevines of Cabernet Franc but no other biological information is known (23).

We next investigated whether the GRBaV found in deep sequencing was also present in the source vines that had been marked in fall 2010 when dormant canes were collected for metagenomic analysis. The three contigs generated from Illumina reads of sources CF214, CS337, and Z1A, with lengths of 1,711, 3,224, and 3,342 nt, respectively, were aligned using CLUSTALW, and two primers, GRBVF1 and GRBVR1, were designed to amplify a 557-bp product. These primers amplified a product of expected size from the cDNA library samples submitted for deep sequencing and also from NA obtained from leaf petioles of diseased source vines. Sequences of the amplified products were verified to be identical to the virus sequences obtained by deep sequencing.

Graft-transmissibility is a key feature of plant viruses in establishing disease etiology (35). Transmission of GRBaV was verified by grafting chip buds of three diseased source vines on test plants of CF01 maintained under greenhouse conditions. Systemic movement of the virus into the leaves distal to the grafted sites was detected at 11 months after inoculation by PCR assays (Table 2). However, the grafted plants did not show any of the red blotch symptoms during the 1-year postinoculation period.

The full genome of GRBaV was determined by sequencing a $3.2-\mathrm{kb}$ product obtained by PCR amplification using two overlapping primers, GVG01 and GVG02, as well as from amplified products obtained from RCA. The complete sequence of the GRBaV isolate CF-214-1 from CF214 was 3,206 nt long. This length was identical to that of GCFaV and slightly bigger than the 3,080-nt-long genome of Horseradish curly top virus (genus Curtovirus, family Geminiviridae), a monopartite geminivirus (20).

Recently, another new DNA virus with a genome size of $3.64 \mathrm{~kb}$ was found associated with citrus chlorotic dwarf disease (27). Based on the genome organization, the new virus was described as a geminivirus, and was provisionally named Citrus

TABLE 2. Detection of Grapevine red blotch-associated virus (GRBaV) by polymerase chain reaction in Cabernet Franc test plants graft inoculated with chip buds from grapevines showing red blotch symptoms

\begin{tabular}{llccc}
\hline & \multicolumn{1}{c}{ Cultivar } & Number tested & Petioles & Roots \\
\cline { 3 - 5 } Status & Cabernet Franc 214 & 5 & 4 & 2 \\
Symptomatic & Cabernet Sauvignon 337 & 5 & 2 & 4 \\
& Zinfandel 1A & 5 & 0 & 0 \\
Healthy & Cabernet Franc & 3 & 0 & 0 \\
Ungrafted control & $\ldots$ & 3 & 0 & 0 \\
\hline
\end{tabular}


chlorotic dwarf-associated virus $(\mathrm{CCDaV})$. Citrus chlorotic dwarf disease has been known for several decades and the causal agent is known to be transmitted by bayberry whitefly (Parabemisia myricae, family Aleyrodidae) (22). Both monopartite and bipartite members of the genus Begomovirus of the family Geminiviridae are known to be transmitted by sweetpotato whitefly (Bemicia tabaci). Restriction fragment analysis of RCA-amplified products indicated the presence of only one circular DNA molecule in three diseased sources, indicating that the GRBaV genome is composed of a single circular DNA molecule, monopartite, much like $\mathrm{CCDaV}$ (Fig. 4). From research on sap-transmissible bipartite geminiviruses, it is known that geminiviruses have constraint on the size of the individual DNA components $(9,12)$. It will be interesting to study how monopartite DNA viruses such as $\mathrm{CCDaV}$ and GRBaV could overcome this constraint.

This study has provided evidence for the association of a monopartite DNA virus with grapevine red blotch disease. The PCR assay developed here will be useful in future studies on the incidence, spread, and epidemiology of GRBaV and to assess the effect of this virus on vineyard health.

\section{ACKNOWLEDGMENTS}

This work was supported partly by a grant from the Viticulture Consortium West to M. R. Sudarshana. We thank the grower cooperators in Napa Valley for providing vineyard access and assistance over the course of this investigation and S. Gonzalez for assistance with NA extractions. Mention of a trademark, proprietary products, or vendor does not constitute guarantee or warranty of the product by the United States Department of Agriculture and does not imply its approval to the exclusion of other products and vendors that might also be suitable.

\section{LITERATURE CITED}

1. Abou Ghanem-Sabanadzovic, N., Sabanadzovic, S., Uyemoto, J. K., Golino, D., and Rowhani, A. 2010. A putative new ampelovirus associated with grapevine leafroll disease. Arch. Virol. 155:1871-1876.

2. Al Rwahnih, M., Daubert, S., Golino, D., and Rowhani, A. 2009. Deep sequencing analysis of RNAs from a grapevine showing Syrah decline symptoms reveals a multiple virus infection that includes a novel virus. Virology 387:395-401.

3. Al Rwahnih, M., Dolja, V. V., Daubert, S., Koonin, E. V., and Rowhani, A. 2012. Genomic and biological analysis of Grapevine leafroll-associated virus 7 reveals a possible new genus within the family Closteroviridae. Virus Res. 163:302-309.

4. Al Rwahnih, M., Rowhani, A., Smith, R. J., Uyemoto, J. K., and Sudarshana, M. R. 2012. Grapevine necrotic union, a newly recognized disease of unknown etiology in grapevines grafted on 110 Richter rootstock in California. J. Plant Pathol. 94:149-156.

5. Al Rwahnih, M., Sudarshana, M. R., Uyemoto, J. K., and Rowhani, A. 2012. Complete genome sequence of a novel vitivirus isolated from grapevine. J. Virol. 86:9545

6. Altschul, S. F., Madden, T. L., Schäffer, A., Zhang, J., Zhang, Z., Miller, W., and Lipman, D. J. 1997. Gapped BLAST and PSI-BLAST: A new generation of protein database search programs. Nucleic Acids Res. 25:3389-3402.

7. Bertazzon, N., Borgo, M., Vanin, S., and Angelini, E. 2010. Genetic variability and pathological properties of Grapevine leafroll-associated virus 2 isolates. Eur. J. Plant Pathol. 127:185-197.

8. Calvi, B. L. 2011. Effects of red-leaf disease on Cabernet Sauvignon at the Oakville experimental vineyard and mitigation by harvest delay and crop adjustment. MS thesis, University of California, Davis.

9. Elmer, S., and Rogers, S. G. 1990. Selection for wild type size derivatives of tomato golden mosaic virus during systemic infection. Nucleic Acids Res. 18:2001-2006.

10. Fuchs, M., Marsella-Herrick, P., Loeb, G. M., Martinson, T. E., and Hoch, H. C. 2009. Diversity of ampeloviruses in mealybug and soft scale vectors and in grapevine hosts from leafroll-affected vineyards. Phytopathology 99:1177-1184.

11. Giampetruzzi, A., Roumi, V., Roberto, R., Malossini, U., Yoshikawa, N., La Notte, P., Terlizzi, F., Credi, R., and Saldarelli, P. 2012. A new grapevine virus discovered by deep sequencing of virus- and viroidderived small RNAs in cv. Pinot gris. Virus Res. 163:262-268.

12. Gilbertson, R. L., Sudarshana, M., Jiang, H., Rojas, M. R., and Lucas, W. J. 2003. Limitations on geminivirus genome size imposed by plasmo- desmata and virus-encoded movement protein: Insights into DNA trafficking. Plant Cell 15:2578-2591.

13. Goheen, A. C. 1990. Leafroll. Page 52 in: Compendium of Grape Diseases R. Pearson and A. C. Goheen, eds. American Phytopathological Society, St. Paul, MN.

14. Golino, D. 1992. Latent virus effect on alternative rootstocks. Am. J Enol. Viticult. 43:300.

15. Golino, D., Sim, S., and Rowhani, A. 2000. Identification of the latent viruses associated with young vine decline in California. Pages 85-86 in: Proc. 13th Int. Counc. Study Viruses Virus-like Dis. Grapevine, Adelaide, Australia R. H. Symons, ed.

16. Golino, D. A., Sim, S. T., Gill, R., and Rowhani, A. 2002. California mealybugs can spread grapevine leafroll disease. Calif. Agric. 56:196201.

17. Haible, D., Kober, S., and Jeske, H. 2006. Rolling circle amplification revolutionizes diagnosis and genomics of geminiviruses. J. Virol. Methods 135:9-16.

18. Jarugula, S., Alabi, O. J., Martin, R. R., and Naidu, R. A. 2010. Genetic variability of natural populations of Grapevine leafroll-associated virus 2 in Pacific Northwest vineyards. Phytopathology 100:698-707.

19. Klaassen, V. A., Sim, S. T., Dangl, G. S., Osman, F., Al Rwahnih, M., Rowhani, A., and Golino, D. A., 2011. Vitis californica and Vitis californica $\times$ Vitis vinifera hybrids are hosts for Grapevine leafrollassociated virus-2 and -3 , and grapevine vitivirus A and B. Plant Dis. 95:657-665.

20. Klute, K. A., Nadler, S. A., and Stenger, D. C. 1996. Horseradish curly top virus is a distinct subgroup II geminivirus species with rep and C4 genes derived from a subgroup III ancestor. J. Gen. Virol. 77:1369-1378.

21. Komar V., Vigne, E., Demangeat, G., and Fuchs, M. 2007. Beneficial effect of selective virus elimination on the performance of Vitis vinifera cv. Chardonnay. Am. J. Enol. Viticult. 58:202-210.

22. Korkmaz, S., Cinar, A., Kersting, U., and Garnsey, S. M. 1995. Citrus chlorotic dwarf: A new whitefly-transmitted virus-like disease of citrus in Turkey. Plant Dis. 79:1074.

23. Krenz, B., Thompson, J. R., Fuchs, M., and Perry, K. L. 2012. Complete genome sequence of a new circular DNA virus from grapevine. J. Virol. $86: 7715$.

24. Kreuze, J. F., Perez, A., Untiveros, M., Quispe, D., Fuentes, S., Barker, I., and Simon, R. 2009. Complete viral genome sequence and discovery of novel viruses by deep sequencing of small RNAs: A generic method for diagnosis, discovery and sequencing of viruses. Virology 388:1-7.

25. Lee, J., and Martin, R. R. 2009. Influence of grapevine leafroll associated viruses (GLRaV-2 and -3) on the fruit composition of Oregon Vitis vinifera L. cv. Pinot noir: Phenolics. Food Chem. 112:889-889.

26. Le Maguet, J., Beuve, M., Herrbach, E., and Lemaire, O. 2012. Transmission of six ampeloviruses and two vitiviruses to grapevine by Phenacoccus aceris. Phytopathology 102:717-723.

27. Loconsole, G., Saldarelli, P., Doddapaneni, H., Savino, V., Martelli, G. P., and Saponari, M. 2012. Identification of a single-stranded DNA virus associated with citrus chlorotic dwarf disease, a new member in the family Geminiviridae. Virology 432:162-172.

28. Martelli, G. P., Abou Ghanem-Sabanadzovic, N., Agranovsky, A. A., Al Rwahnih, M., Dolja, V. V., Dovas, C. I., Fuchs, M., Gugerli, P., Hu, J. S., Jelkmann, W., Katis, N. I., Maliogka, V. I., Melzer, M. J., Menzel, W., Minafra, A., Rott, M. E., Rowhani, A., Sabanadzovic, S., and Saldarelli, P. 2012. Taxonomic revision of the family Closteroviridae with special reference to the Grapevine leafroll-associated members of the genus Ampelovirus and the putative species unassigned to the family. J. Plant Pathol. 94:7-19.

29. Martelli, G. P., and Boudon-Padieu, E. 2006. Directory of infectious diseases of grapevines. Opt. Méditerr. Ser. B. 55:59-75.

30. Morales, R. Z., and J. Monis, J. 2007. First detection of Grapevine leafroll-associated virus-7 in California vineyards. Plant Dis. 91:465.

31. Nakaune, R., Toda, S., Mochizuki, M., and Nakano, M. 2008. Identification and characterization of a new vitivirus from grapevine. Arch Virol. 153:1827-1832.

32. Osman F., Leutenegger C., Golino D. A., and Rowhani A. 2008. Comparison of low-density arrays, RT-PCR and real-time TaqMan RTPCR in detection of grapevine viruses. J. Virol. Methods 149:292-299.

33. Pantaleo, V., Saldarelli, P., Miozzi, L., Giampetruzzi, A., Gisel, A., Moxon, S., Dalmay, T., Bisztray, G., and Burgyan, J. 2009. Deep sequencing analysis of viral short RNAs from an infected Pinot noir grapevine. Virology 408:49-56.

34. Routh, G., Zhang, Y.-P., Saldarelli, P., and Rowhani, A. 1998. Use of degenerate primers for partial sequencing and RT-PCR-based assays of grapevine leafroll-associated viruses 4 and 5. Phytopathology 88:12381243.

35. Rowhani, A., Uyemoto, J. K., Golino, D. A., and Martelli, G. P. 2005. Pathogen testing and certification of Vitis and Prunus species. Annu. Rev. Phytopathol. 43:261-278. 
36. Thomas, J. E., Parry, J. N., Schwinghamer, M. W., and Dann, E. K. 2010. Two novel mastreviruses from chickpea (Cicer arietinum) in Australia. Arch. Virol. 155:1777-1788.

37. Tsai, C.-W., Chau, J., Fernandez, L., Bosco, D., Daane, K. M., and Almeida, R. P. P. 2008. Transmission of Grapevine leafroll-associated virus 3 by the vine mealybug (Planococcus ficus). Phytopathology 98:1093-1098.

38. Uyemoto, J. K., Rowhani, A., Luvisi, D., and Krag, R. C. 2001. New closterovirus in 'Red globe' grape causes decline of grafted plants. Calif. Agric. 55:28-31.

39. Zerbino, D. R., and Birney, E. 2008. Velvet: Algorithms for de novo short read assembly using de Bruijn graphs. Genome Res. 18:821-829.

40. Zhang, Y., Singh, K., Kaur, R., and Qiu, W. 2011. Association of a novel DNA virus with the grapevine vein-clearing and vine decline syndrome. Phytopathology 101:1081-1090. 